\title{
ターゲットスクリーニング分析と生物応答試験による 豪雨災害時における河川水中有機污染物質の調査
}

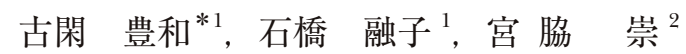

\section{1 緒言}

近年, 我が国では豪雨による河川汇濫などの自然災害が 頻発している。災害発生時には建物の倒壊や冠水によっ て, 有害化学物質の漏洩や流出による二次災害が懸念され る.このような緊急時では, 流出した有害化学物質を速や かに調查し，污染の拡大防止を図ることで，地域住民の生 活を守る必要がある。緊急時における環境調查の必要性は 「国土強勒化計画」や「防災基本計画」に明記されている が，平常時と異なる一種の極限環境下となる災害発生時で は, 環境基準物質のみを測定し安全性を評価するのは困難 である122).

そこで，標準物質を使用することなく多成分の化学物質 を自動同定・定量する手法として GC/MS 自動同定・定量 データベースシステム (AIQS) が Kadokami ら（2005）に より開発された . 著者らは，この AIQS を用いた多成分の 有機污染物質を迅速かつ多検体処理できるターゲットスク リーニング手法（以下，スクリーニング法）を開発し，さ らに, 不揮発性の物質や親水性の高い物質などAIQS に登 録されていない物質については, 広く普及している四重極 型のLC/MS/MSによるスクリーニング法（MRMによる多 成分一斉分析法）を開発してきた4) 6).

さらに，著者らはスクリーニング法に加え，環境省が導 入を検討していた「生物応答を用いた排水管理手法（日本 版 WET)」に関する研究に取り組んできた7). 日本版 WET で用いられる生物応答試験は, 機器分析で把握困難な化学 物質の毒性や相乗・敦抗作用などの複合的な影響を検知で き, 災害時において流出化学物質を含む水試料全体の毒性 を把握できる利点がある，福岡県では，緊急時における有 機污染物質のスクリーニング法を補完する方法として, 生 物応答を組み合わせた新しい水質評価法を考案し, 緊急時 環境調查に対応できる体制を整えているところである。

九州では 2020（令和 2）年 7 月初旬から下旬にかけて,

\footnotetext{
* E-mail : t-koga@fihes.pref.fukuoka.jp

1 福岡県保健環境研究所 : 818-0135 福岡県太宰府市向佐野 39

2 北九州市立大学：808-0135 福岡県北九州市若松区ひびきの $1-1$
}

「令和 2 年豪雨」と呼ばれる人的被害や物的被害を伴った 豪雨災害が発生した ${ }^{8)}$. この豪雨災害において筑後川水系 河川の上流域で河川沿いの農薬倉庫が倒壞し, 保管されて いた農薬 $(1104 \mathrm{~kg})$ の一部が容器ごと河川へ流出した ${ }^{8}$. その報告を受け，下流の環境基準点にて緊急時環境調查を 実施した。

本稿では, AIQS と LC/MS/MS による有機污染物質のス クリーニング法と生物応答試験を用いた, 緊急時環境調査 を実施した結果について報告する。

$$
2 \text { 実験 }
$$

\section{$2 \cdot 1$ 河川水試料}

河川水試料は, 研究所へ農薬流出の連絡があった 2020 年 7 月 10 日に, 筑後川河口から約 $14.7 \mathrm{~km}$ 上流にある環 境基準点においてポリバケッにて橋上から採水し， $1 \mathrm{~L}$ ポ リ容器と $1 \mathrm{~L}$ ガラス瓶に入れて研究所へ搬入した。採水時 の天候は雨であり，河川は濁っていた（Fig. 1)。な㧍，採 水当日と前日の降水量の合計は $223.5 \mathrm{~mm}$ であった ${ }^{9)}$.

\section{$2 \cdot 2$ 測定項目}

測定項目は流出した農薬類である Cypermethrin, Phenthoate, Chlorfenapyr, Tralomethrin, Tolfenpyrad, Tefluthrin, Imidacloprid, Methomyl, Acetamiprid, Iminoctadine, Diquat, Paraquatの 12 種類である。それぞ れの物性值について Table 1 に示す.

また, 流出農薬以外の測定項目として DO, pH, EC, $\mathrm{COD}, \mathrm{BOD}, \mathrm{SS}$ ，アンモニウム態窒素 $\left(\mathrm{NH}_{4} \mathrm{-} \mathrm{N}\right)$ を測定し た.

\section{$2 \cdot 3$ 流出農薬の情報収集と測定機器選択}

本稿の事例では, 豪雨災害で農薬の入った容器ビンごと 河川へ流出したため, 農薬ハンドブックより, 製品名から 含有する農薬成分の特定と物性值・毒性値調查を実施し た ${ }^{10)}$. 測定機器選択について, 本稿で用いたスクリーニン グ法で適用可能な化学物質の物性值 (Log Pow) は GC/MS と LC/MS/MS で, それぞれ $0.78 \sim 7.05$ と - 0.46〜 8.20で あり, 機器選択の目安として Log Pow が 2 以上であれば 
GC/MS を選択し, Log Pow が 2 以下であればLC/MS/MS を選択した ${ }^{4) 5)}$. 流出農薬の情報収集の結果, Cypermethrin, Phenthoate, Chlorfenapyr, Tralomethrin, Tolfenpyrad, Tefluthrinの 6 種類は AIQS に登録済みであり, Log Pow も 3.69 ～ 7.56 の範囲であったことから， GC/MS 測定を行 うこととした $(n=1)$. そして Imidacloprid, Methomyl, Acetamiprid, Iminoctadine, Diquat, Paraquat $の 6$ 種類に ついては LC/MS/MS にて測定を行った $(n=1)$.

\section{$2 \cdot 4$ 試薬及び器具}

スクリーニング法に使用した有機溶媒は, 富士フイルム
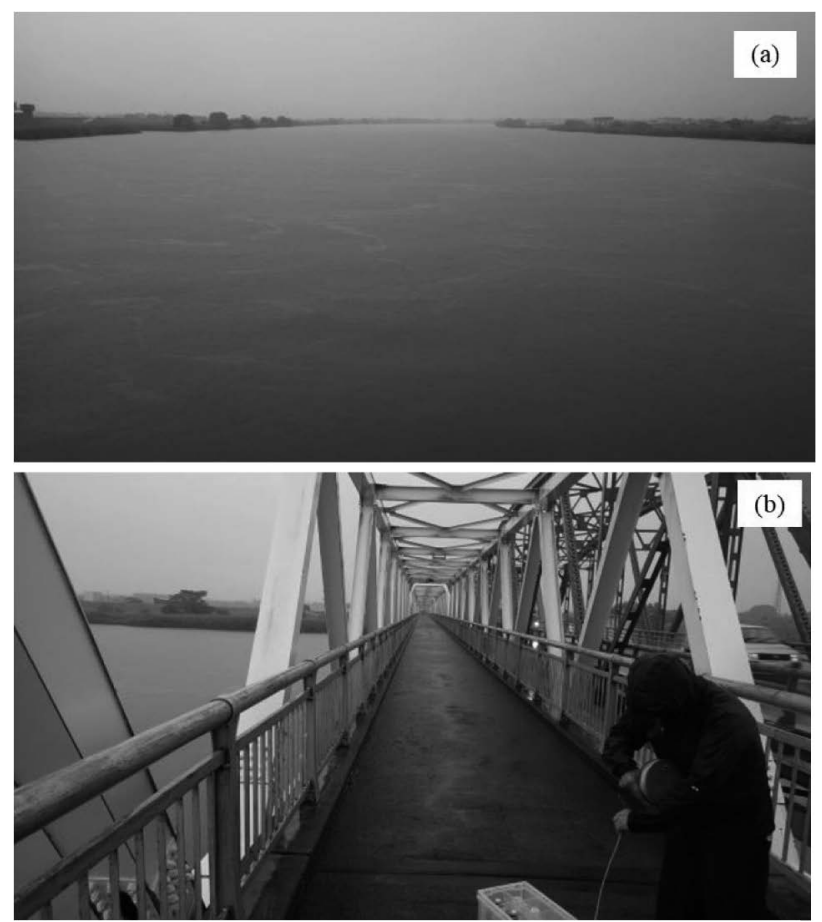

Fig. 1 Sampling point

(a) River condition in heavy rain disaster. (b) Water sampling from the bridge.
和光純薬製のアセトン, ジクロロメタン（残留農薬・PCB 試験用), アセトニトリル, メタノール, ギ酸 (LC/MS 用), $1 \mathrm{~mol} \mathrm{~L}^{-1}$ 酢酸アンモニウム溶液 (高速液体クロマトグラフ 用), 塩化ナトリウム（水質試験用）及び関東化学製の蒸留 水（LC/MS 用）である.

内標準物質として GC/MS 測定用は, Restek 製の Custom Internal Standard (1000 $\mathrm{mg} \mathrm{L}^{-1}$, 4-Chlorotoluene-d ${ }_{4}$, 1,4-Dichlorobenzene- $\mathrm{d}_{4}$, Naphthalene- $\mathrm{d}_{8}$, Acenaphthene- $\mathrm{d}_{10}$, Phenanthrene- $\mathrm{d}_{10}$, Fluoranthene- $\mathrm{d}_{10}$, Chrysene-d $\mathrm{d}_{12}$, Perylene-d $\mathrm{d}_{12}$ ) を用い, ジクロロメタンにて $1 \mathrm{mg} \mathrm{L}^{-1} に$ 希釈 した．LC/MS/MS 測定用は，林純薬工業製の PL 農薬サロ ゲート混合標準溶液 III（各 $20 \mathrm{mg} \mathrm{L}^{-1}$ ，アセトニトリル溶 液, Methomyl- $\mathrm{d}_{3}$, Thiabendazole $-{ }^{13} \mathrm{C}_{6}$, Imidacloprid- $\mathrm{d}_{4}$, Imazalil- $\mathrm{d}_{5}$, Carbaryl- $\left.\mathrm{d}_{7}\right)$ と Wellington laboratories 製 の MPFAC-C-ES (2 mg L ${ }^{-1}$, Perfluoro-n- $\left[{ }^{13} \mathrm{C}_{4}\right]$ butanoic acid, Perfluoro-n- $\left[{ }^{13} \mathrm{C}_{5}\right]$ pentanoic acid, Perfluoro-n-[1,2,3,4,6$\left.{ }^{13} \mathrm{C}_{5}\right]$ hexanoic acid, Perfluoro-n- $\left[1,2,3,4-{ }^{13} \mathrm{C}_{4}\right]$ heptanoic acid, Perfluoro-n- $\left[{ }^{13} \mathrm{C}_{8}\right]$ octanoic acid, Perfluoro-n- $\left[{ }^{13} \mathrm{C}_{9}\right]$ nonanoic acid, Perfluoro-n-[1,2,3,4,5,6- $\left.{ }^{13} \mathrm{C}_{6}\right]$ decanoic acid, Perfluoro-n-[1,2,3,4,5,6,7- $\left.{ }^{13} \mathrm{C}_{7}\right]$ undecanoic acid, Perfluoro-n- $\left[1,2-{ }^{13} \mathrm{C}_{2}\right]$ dodecanoic acid, Perfluoro-n-[1,2$\left.{ }^{13} \mathrm{C}_{2}\right]$ tetradecanoic acid, Sodium perfluoro-1-[2,3, $\left.4-{ }^{13} \mathrm{C}_{3}\right]$ butanesulfonate, Sodium perfluoro-1-[1,2,3- $\left.{ }^{13} \mathrm{C}_{3}\right]$ hexanesulfonate, Sodium perfluoro-1- $\left[{ }^{13} \mathrm{C}_{8}\right]$ octanesulfonate) を 用いた. LC/MS/MS 測定用の内部標準物質はすべて, アセ トニトリルにて $0.02 \mathrm{mg} \mathrm{L}^{-1}$ に調製した.

GC/MS によるスクリーニング法の添加回収試験用の標 準溶液は, 富士フイルム和光純薬製の 66 種農薬混合標準 液水質 -1-2（各 $20 \mathrm{mg} \mathrm{L}^{-1}$, アセトン溶液）を用いた.

LC/MS/MS スクリーニング法の標準物質は，林純薬工 業製の農薬 66 種混合標準溶液（各 $10 \mathrm{mg} \mathrm{L}^{-1}$, アセトニト リル溶液, LC/MS/MS 用), 2003 水道水水質試験用農薬混 合標準溶液 III（各 $10 \mathrm{mg} \mathrm{L}^{-1}$, アセトニトリル溶液）と富

Table 1 Physical properties of targeted pesticides

\begin{tabular}{|c|c|c|c|c|c|}
\hline No & Compounds & $\log P_{\text {ow }}{ }^{\mathrm{ab} b}$ & $\begin{array}{l}\text { Water solubility/ } \\
\mathrm{mg} \mathrm{L}^{-1 \mathrm{a}) \mathrm{b})}\end{array}$ & $\begin{array}{l}\text { Acute toxicity to fish, } \\
\qquad \mathrm{LC}_{50} / \mathrm{mg} \mathrm{L}^{-1} \text { a) }\end{array}$ & $\begin{array}{l}\text { Acute toxicity to algae, } \\
\qquad \mathrm{EC}_{50} / \mathrm{mg} \mathrm{L}^{-1 \text { a) }}\end{array}$ \\
\hline 1 & Cypermethrin & 6.6 & 0.004 & 0.09 & $>19$ \\
\hline 2 & Phenthoate & 3.69 & 11 & 2.5 & - \\
\hline 3 & Chlorfenapyr & 4.83 & 0.112 & 0.1 & $>0.551$ \\
\hline 4 & Tralomethrin & 7.56 & 0.08 & 0.00049 & 1.56 \\
\hline 5 & Tolfenpyrad & 5.61 & 0.087 & 0.0029 & $>0.76$ \\
\hline 6 & Tefluthrin & 6.5 & 0.02 & 0.000102 & $>1.8$ \\
\hline 7 & Imidacloprid & 0.57 & 610 & 170 & $>100$ \\
\hline 8 & Methomyl & 0.6 & 58000 & 3.58 & $>94$ \\
\hline 9 & Acetamiprid & 0.80 & 4250 & $>100$ & $>98.3$ \\
\hline 10 & Iminoctadine & 2.71 & 764000 & $27^{c)}$ & $0.0050^{c)}$ \\
\hline 11 & Diquat & -4.6 & 718000 & 67 & 0.019 \\
\hline 12 & Paraquat & -4.22 & 620000 & 136 & 0.24 \\
\hline
\end{tabular}

a) Reference 10, b) Reference 22, c) Iminoctadine triacetate. 


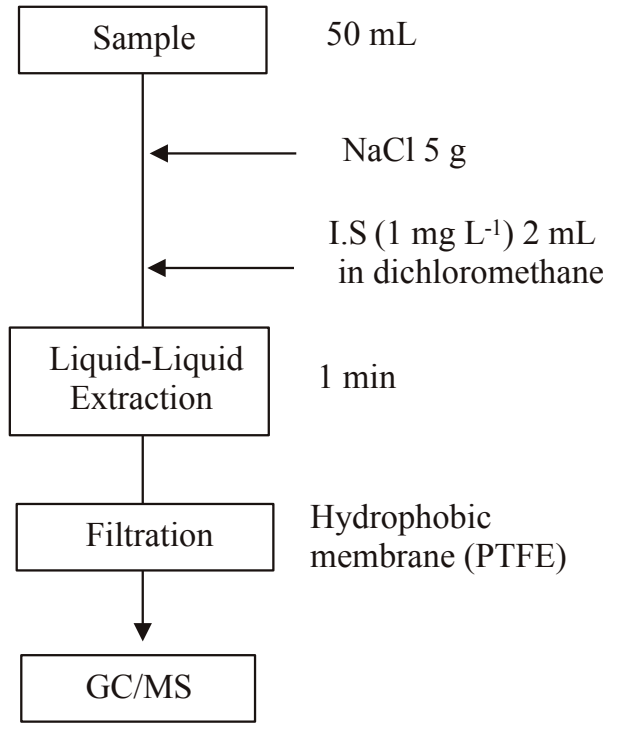

Fig. 2 Method of target screening by GC/MS

士フイルム和光純薬製の 28 種農薬混合標準液水質 -3 (各 $20 \mathrm{mg} \mathrm{L}{ }^{-1}$, アセトニトリル溶液) を用いた. Iminoctadine, Diquat, Paraquat の測定には，富士フイルム和光純薬製の 農薬混合標準液水質 -7（各 $20 \mathrm{mg} \mathrm{L}^{-1}$, 水溶液）を用いた.

藻類生長阻害試験では, 富士フイルム和光純薬製の OECD 培地濃縮液 I, OECD 培地濃縮液 II, OECD 培地濃 縮液 III, OECD 培地濃縮液 IV を用いた.

ミジンコ急性遊泳阻害試験では, 試験キットの Daphtoxkit F magna（Microbiotests Inc.）を用いた。試験に用いた飼 育水は, 試験キット付属の濃縮塩溶液を $2 \mathrm{~L}$ ガラスメスフ ラスコに全量入れ, 超純水 (RFU665DA, アドバンテック 東洋製）で希釈したものを使用した。

魚類胚期急性毒性試験では, 試験容器にアズワン製の 24 ウェルプレート（Violamo 細胞培養プレート VTC-P24）を 用いた。陽性対照区の使用物質として，東京化成工業製の 3,4-dichloroaniline を用いた.

流出農薬の前処理に用いた器具は, ジーエルサイエンス 製の迅速前処理カートリッジである. これは, 材質として ポリプロピレン製の抽出器具で構成されており, $60 \mathrm{~mL} リ$

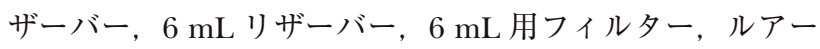
ストップバルブ, 疎水性膜の PTFE メンブレンフィルター, クランプ, $50 \mathrm{~mL}$ ディスポシリンジがセットになっている 液液抽出用製品である. また, Iminoctadine, Diquat, Paraquat 測定では， $1 \mathrm{~mL}$ シリンジ（テルモ製）と，ろ過 ディスク (Acrodisc Syringe Filter, 13 mm, $0.2 \mu \mathrm{m}$, PTFE Minispike, Waters 製) と, ポリプロピレンバイアル（Waters 製）を用いた。

2·5 GC/MS によるスクリーニング法

GC/MS による流出農薬のスクリーニング法は, 既報を

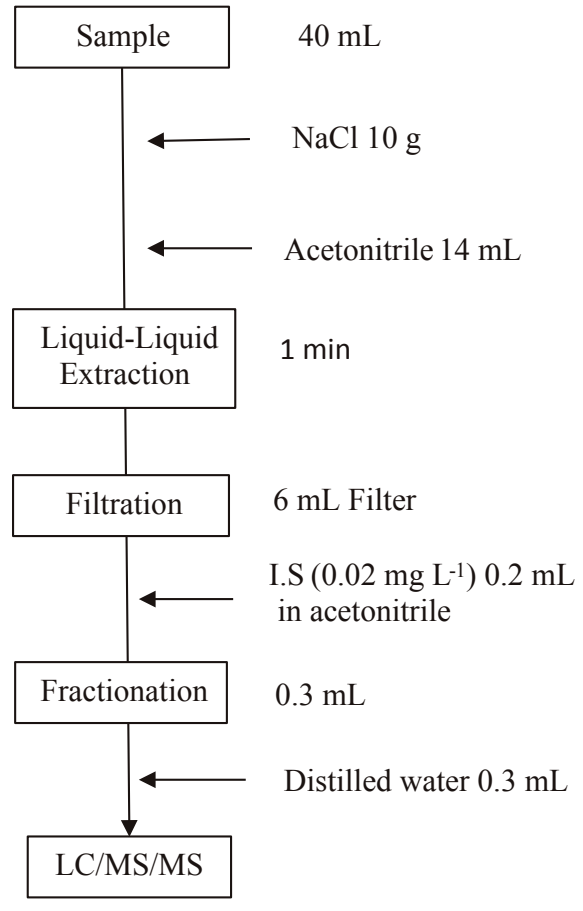

Fig. 3 Method of target screening by LC/MS/MS

参考に実施した ${ }^{4)}$.

GC/MS 用の前処理フローを Fig. 2 に示す。まず迅速前

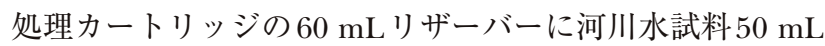
と塩化ナトリウム $5 \mathrm{~g}$ を入れ, 内部標準物質 $\left(1 \mathrm{mg} \mathrm{L}^{-1}\right)$ 含 有のジクロロメタンを $2 \mathrm{~mL}$ 添加し, 1 分間振とう抽出し た. 2 分間静置後, $6 \mathrm{~mL}$ 用フィルターと疎水性膜を取り付

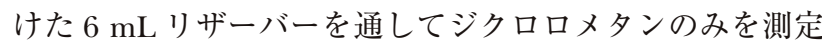
用ガラスバイアルに回収した.

測定対象物質のうち Cypermethrin, Phenthoate, Chlorfenapyr, Tralomethrin, Tolfenpyrad, Tefluthrin の 6 種類 は，GC/MS によるスクリーニング法で測定した。

\section{2・6 LC/MS/MS によるスクリーニング法}

LC/MS/MS を用いた流出農薬のスクリーニング法は, 既報を参考に実施した ${ }^{5)}$.

LC/MS/MS 用の前処理フローを Fig. 3 に示す. LC/MS/ MS 用の前処理は, 迅速前処理カートリッジの $60 \mathrm{~mL} リ$ ザーバーに水試料 $40 \mathrm{~mL}$ と塩化ナトリウム $10 \mathrm{~g}$ を入れ, ア セトニトリル $14 \mathrm{~mL}$ 添加後に 1 分間振とう抽出した. 2 分 間静置後, 分離したアセトニトリルを $6 \mathrm{~mL}$ 用フィルター

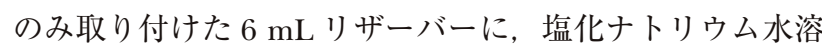
液（蒸留水 $40 \mathrm{~mL}$ に対し塩化ナトリウム $10 \mathrm{~g}$ 添加）を満 たした $50 \mathrm{~mL}$ ディスポシリンジを用いて河川水試料と分 離したアセトニトリルを，塩化ナトリウム水溶液で押し出 してろ過した。これに内部標準物質 $\left(0.02 \mathrm{mg} \mathrm{L}^{-1}\right)$ を 0.2 $\mathrm{mL}$ 添加したのちにポリプロピレンバイアルへ $0.3 \mathrm{~mL}$ 分取 したあと, 蒸留水を $0.3 \mathrm{~mL}$ 添加して測定用試料とした. 
Table 2 Analytical conditions for GC/MS screening

\begin{tabular}{cll}
\hline Instrument & Agilent 5977B GC/MSD & \\
\hline \multirow{2}{*}{ GC conditions } & Column & $:$ J\&B DB-5MS, $30 \mathrm{~m} \times 0.25 \mathrm{~mm} \times 0.25 \mu \mathrm{m}$ (Agilent) \\
& Oven temp. & $: 40{ }^{\circ} \mathrm{C}(2 \mathrm{~min}) \rightarrow 8{ }^{\circ} \mathrm{C} / \mathrm{min} \rightarrow 310^{\circ} \mathrm{C}(5 \mathrm{~min})$ \\
& Injection temp. & $: 250^{\circ} \mathrm{C}$ \\
& Interface temp. & $: 280^{\circ} \mathrm{C}$ \\
& Injection mode & $:$ Splitless \\
& Injection volume & $: 1 \mu \mathrm{L}$ \\
MS conditions & Ionization mode & $:$ EI $(70 \mathrm{eV})$ \\
& Source temp. & $: 230^{\circ} \mathrm{C}$ \\
& Quadrupole temp. & $: 150{ }^{\circ} \mathrm{C}$ \\
& Scan range & $: 33-550 \mathrm{~m} / z$ \\
& Scan rate & $: 2.8 \mathrm{scan} / \mathrm{sec}$ \\
\hline
\end{tabular}

測定対象物質のうち Imidacloprid, Methomyl, Acetamiprid は, LC/MS/MS によるスクリーニング法で測定した.

\subsection{Iminoctadine, Diquat, Paraquat $の$ 測定}

Iminoctadine, Diquat, Paraquatについては, 水溶解度 がそれぞれ $764000 \mathrm{mg} \mathrm{L}^{-1}, 718000 \mathrm{mg} \mathrm{L}^{-1}, 620000 \mathrm{mg} \mathrm{L}^{-1}$ と非常に親水性が高く, 開発した LC/MS/MS スクリーニ ング法では測定が困難であると考えられた ${ }^{4) 5)}$.

小林ら（2015）は, 固相抽出カートリッジ (Oasis WCX) を用いた測定法を報告している ${ }^{11)}$. しかし，今回のように 突発的に発生した豪雨災害において固相抽出カートリッジ を準備できなかったため, 今回の緊急時環境調査では LC/ $\mathrm{MS} / \mathrm{MS}$ へ直接注入する方法で測定を行った. 河川水試料 はSS が多く LC 配管やカラムの詰まりを引き起こすことが 予想されたため, $1 \mathrm{~mL}$ シリンジで河川水試料をとり, ろ 過ディスクでろ過後にポリプロピレンバイアルに分取し測 定に供した。

\section{$2 \cdot 8$ 添加回収試験}

河川水試料を用いた本調査の対象物質について添加回収 試験を実施した。スクリーニング法の添加回収試験の方法 は既報に従い，目標值は 50〜 $150 \%$ とした ${ }^{4) 5)}$.

$\mathrm{GC} / \mathrm{MS}$ によるスクリーニング法では, 河川水試料 50 $\mathrm{mL}$ に GC/MS スクリーニング法の標準物質 $200 \mathrm{ng}$ を添加 し, $2 \cdot 5$ の方法に従って測定した $(n=3)$. ただし, 標準物 質の入手が困難であった測定対象物質については, 物性 (Log Pow) が近い農薬で評価した. Cypermethrin, Tralomethrin, Tefluthrin は, Etofenprox で評価し, Chlorfenapyr は Chlorpyrifos, Benfluralin, Dithiopyr で評価した。また Tolfenpyrad は Trifluralin で評価した.

LC/MS/MS によるスクリーニング法では, 河川水試料 $40 \mathrm{~mL}$ にC $/ \mathrm{MS} / \mathrm{MS}$ スクリーニング法の標準物質を 200 $n g$ 添加し， 2・6 の方法に従って測定した $(n=3)$.

Iminoctadine, Diquat, Paraquatの測定では, 河川水試 料 $5 \mathrm{~mL}$ に農薬混合標準液水質 -7 を $250 \mathrm{ng}$ 添加し, $2 \cdot 7$ の
方法に従って測定した $(n=3)$.さらに, 使用したろ過ディ スクへの吸着率を測定するため, 蒸留水に農薬混合標準液 水質 -7を $250 \mathrm{ng}$ 添加し， ろ過ディスクでろ過したものを 測定した $(n=3)$.

\section{$2 \cdot 9$ 操作ブランク試験}

蒸留水を用いて操作ブランク試験を行った。本試験で は, 標準物質を添加せず, $2 \cdot 5,2 \cdot 6,2 \cdot 7$ と同様の操作で 実施した。

\section{$2 \cdot 10 \mathrm{GC} / \mathrm{MS}$ 測定条件}

測定には，四重極型 GC/MS（Agilent 製，5977B GC/ MSD）を用いた。測定条件を Table 2 に示す. 同定と定量 は，データベースソフト NAGINATA II（西川計測製）を用 いた。

\section{$2 \cdot 11 \mathrm{LC} / \mathrm{MS} / \mathrm{MS}$ 測定条件}

測定には液体クロマトグラフタンデム四重極型質量分析 計（Waters 製，ACQUITY UPLC I-Class/Xevo TQ-S）を用 いた. スクリーニング法の測定条件を Table 3 に示す.

また, Iminoctadine, Diquat, Paraquatの測定条件を Table 4 に示す.

\section{$2 \cdot 12$ 流出農薬以外の測定方法}

pH は, JIS K0102 12.1 ガラス電極法で行った ${ }^{12)}$. EC 測 定は, JISK 0102 13. 電気伝導率にて行った ${ }^{12)} \cdot \mathrm{pH}$ 及び $\mathrm{EC}$ の測定機器は, pH/ECメーター（MM-60R, TOADKK 製) を用いた. BOD は, JISK 0102 21. 生物化学的酸素消費量 (BOD) に従い溶存酸素計（YSI 5000 Dissolved Oxygen Meter, YSI 製) にて測定した ${ }^{12)}$. COD は, JIS K 010217. $100{ }^{\circ} \mathrm{C}$ における過マンガン酸カリウムによる酸素消費量 （CODMn）を参考に実施した ${ }^{12)}$. $\mathrm{NH}_{4} \mathrm{-} \mathrm{N}$ は，JIS K 0102 42.5 イオンクロマトグラフ法により測定した. イオンクロ マトグラフは, Dionex Integrion HPIC システム（Thermo Fisher Scientific 製）を用いた ${ }^{12)}$. 
Table 3 Analytical conditions for LC/MS/MS screening

\begin{tabular}{|c|c|c|c|}
\hline Instrument & & & Waters ACQUITY UPLC I-Class/Xevo TQ-S \\
\hline \multirow[t]{7}{*}{ LC conditions } & Column & : & ACQUITY UPLC BEH C18 $2.1 \mathrm{~mm} \times 100 \mathrm{~mm}, 1.7 \mu \mathrm{m}$ (Waters) \\
\hline & Column temp. & : & $45^{\circ} \mathrm{C}$ \\
\hline & Flow rate & : & $0.45 \mathrm{~mL} \mathrm{~min}{ }^{-1}$ \\
\hline & Mobile phase A & : & $10 \mathrm{mM} \mathrm{CH}_{3} \mathrm{COONH}_{4} / \mathrm{H}_{2} \mathrm{O}$ \\
\hline & Mobile phase B & : & $10 \mathrm{mM} \mathrm{CH}_{3} \mathrm{COONH}_{4} / \mathrm{CH}_{3} \mathrm{OH}$ \\
\hline & Gradient conditions & : & $\begin{array}{l}0.00-0.25 \text { min } \mathrm{A}: \mathrm{B}=98.0 \%: 2.0 \%, 0.25-12.25 \min \mathrm{A}: 98.0 \% \rightarrow 1.0 \%, \mathrm{~B}: 2.0 \% \\
\rightarrow 99.0 \% \text { linear gradient, } 12.25-13.00 \text { min } \mathrm{A}: \mathrm{B}=1.0 \%: 99.0 \%, 13.00-13.01 \\
\min \mathrm{A}: 1.0 \% \rightarrow 98.0 \%, \mathrm{~B}: 99.0 \% \rightarrow 2.0 \% \text { linear gradient, } 13.01-17.00 \mathrm{~min} \\
\mathrm{~A}: \mathrm{B}=98.0 \%: 2.0 \%\end{array}$ \\
\hline & Injection volume & : & $5 \mu \mathrm{L}$ \\
\hline \multirow[t]{7}{*}{ MS conditions } & Ionization mode & : & Positive/Negative-ESI \\
\hline & Detection mode & : & MRM \\
\hline & $\begin{array}{l}\text { Monitored ion } \\
(\text { Target chemicals, } m / z)\end{array}$ & : & $\begin{array}{l}\text { Imidacloprid } 256>209 \text {, Acetamiprid } 223>126 \text {, Methomyl } 163.1>88.1 \text {, Imazalil-d }{ }_{5} \\
302>159, \text { PFOA- }{ }^{-13} \mathrm{C}_{8}: 421>376\end{array}$ \\
\hline & Capillary voltages & : & $2900 \mathrm{~V}$ (Positive), $2500 \mathrm{~V}$ (Negative) \\
\hline & Desolvation temp. & : & $550^{\circ} \mathrm{C}$ \\
\hline & Desolvation gas flow & : & $1000 \mathrm{~L} \mathrm{hr}^{-1}$ \\
\hline & Cone gas flow & : & $150 \mathrm{~L} \mathrm{hr}^{-1}$ \\
\hline
\end{tabular}

Table 4 Analytical conditions for Iminoctadine, Diquat, Paraquat

\begin{tabular}{cll}
\hline \multicolumn{1}{c}{ Instrument } & & \multicolumn{1}{c}{ Waters ACQUITY UPLC I-Class/Xevo TQ-S } \\
\hline \multirow{2}{*}{ LC conditions } & Column & $:$ ACQUITY UPLC BEH Amide $1.7 \mu \mathrm{m}, 3.0 \times 100 \mathrm{~mm}$ (Waters) \\
& Column temp. & $: 45^{\circ} \mathrm{C}$ \\
& Flow rate & $: 0.40 \mathrm{~mL} \mathrm{~min}^{-1}$ \\
& Mobile phase & $: 0.1 \% \mathrm{HCOOH} / 150 \mathrm{mM} \mathrm{CH} \mathrm{COONH}_{4} / \mathrm{H}_{2} \mathrm{O}: \mathrm{CH}_{3} \mathrm{CN}=1: 1$ \\
& Injection volume & $: 50 \mu \mathrm{L}$ \\
MS conditions & Ionization mode & $:$ Positive-ESI \\
& Detection mode & $:$ MRM \\
& Monitored ion $(\mathrm{m} / z)$ & $:$ Iminoctadine $178.7>100$, Diquat $183>157.1$, Paraquat $186>171$ \\
& Capillary voltages & $: 2900 \mathrm{~V}$ \\
& Desolvation temp. & $: 550{ }^{\circ} \mathrm{C}$ \\
& Desolvation gas flow & $: 1000 \mathrm{~L} \mathrm{hr}^{-1}$ \\
& Cone gas flow & $: 150 \mathrm{~L} \mathrm{hr}^{-1}$ \\
\hline
\end{tabular}

\section{$2 \cdot 13$ 生物応答試験方法}

河川水試料中の化学物質の複合影響を把握するため, 栄 養段階の異なる 3 種類の水生生物を用いた生物応答試験 (藻類生長阻害試験，ミジンコ急性遊泳阻害試験，魚類胚期 急性毒性試験）を行った.

藻類生長阻害試験は，既報に従った ${ }^{13)}$ 。試験濃度区は対 照区と試料濃度 $80 \%$ の限度試験（連数は対照区を 6 連, 試験濃度区は 3 連）とした。試験期間は 72 時間とした。

ミジンコ急性遊泳阻害試験は, Daphtoxkit F magna 附属 の休眠卵を餒化させて, 孵化後 24 時間以内の仔虫を試験 に用いた。試験濃度区は対照区と試料濃度 $100 \%$ の限度試 験（連数は対照区 4 連, 試験濃度区 4 連, 5 頭/連）とした。 試験期間は 48 時間とした。

魚類胚期急性毒性試験では，ゼブラフィッシュ（Danio rerio）胚を用いた。 ゼブラフィッシュは国立環境研究所水 環境実験施設から分譲された個体を当研究所にて継代し, 3 か月齢以上の親魚から採卵した受精卵を用いた。試験方
法は, OECD TG236 を参考に実施した ${ }^{14)}$. 試験濃度区は, 対照区と 3,4-dichloroaniline (4 $\left.\mathrm{mg} \mathrm{L}^{-1}\right)$ を用いた陽性対照 区と試料濃度 $100 \%$ の限度試験（連数は対照区 6 連, 陽性 対照区と試験濃度区は 5 連で 1 連は Internal plate control, 4 卵/連）とした。試験期間は 96 時間とした。

対照区と試験濃度区の結果比較は, 統計解析ソフト R を 用いて $\mathrm{t}$ 検定もしくは Wilcoxon 検定を実施した ${ }^{15)}$.

\section{3 結果と考察}

\section{$3 \cdot 1$ 流出農薬以外の水質測定結果}

流出農薬以外の水質測定結果を Table 5 に示す. SS と電 気伝導度がそれぞれ $220 \mathrm{mg} \mathrm{L}^{-1}, 65 \mu \mathrm{S} \mathrm{cm}^{-1}$ であった。採 水地点における過去の水質データの平均值は, SS と電気伝

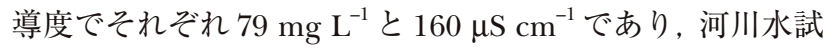
料の SS は定常時よりも高い值となった ${ }^{16)}$. 一方, 電気伝導 度については，定常時の值よりも低い值であったが，これ は雨水の平均值が $19.2 \mu \mathrm{S} \mathrm{cm}^{-1}$ 程度であることを考慮する 
Table 5 Water quality of river water in a heavy rain disaster

\begin{tabular}{|c|c|c|c|c|c|c|c|c|c|}
\hline $\begin{array}{l}\text { Sample } \\
\text { name }\end{array}$ & $\begin{array}{c}\text { Temperature } \\
\left({ }^{\circ} \mathrm{C}\right)\end{array}$ & $\begin{array}{c}\text { Water } \\
\text { temperature } \\
\left({ }^{\circ} \mathrm{C}\right)\end{array}$ & $\begin{array}{c}\mathrm{DO} \\
\left(\mathrm{mg} \mathrm{L}^{-1}\right)\end{array}$ & $\mathrm{pH}$ & $\begin{array}{c}\mathrm{EC} \\
(\mu \mathrm{S} / \mathrm{cm})\end{array}$ & $\begin{array}{c}\mathrm{COD} \\
\left(\mathrm{mg} \mathrm{L}^{-1}\right)\end{array}$ & $\begin{array}{c}\text { BOD } \\
\left(\mathrm{mg} \mathrm{L}^{-1}\right)\end{array}$ & $\begin{array}{c}\mathrm{SS} \\
\left(\mathrm{mg} \mathrm{L}^{-1}\right)\end{array}$ & $\begin{array}{c}\mathrm{NH}_{4}-\mathrm{N} \\
\left(\mathrm{mg} \mathrm{L}^{-1}\right)\end{array}$ \\
\hline River water & 21.5 & 20.2 & 8.9 & 7.2 & 65 & 9.2 & 0.60 & 220 & 0.031 \\
\hline
\end{tabular}

Table 6 Measurement result of river water in a heavy rain disaster by screening method $(n=1)$

\begin{tabular}{clcc}
\hline No & Compounds & $\begin{array}{c}\text { Concentration } \\
\left(\mu \mathrm{g} \mathrm{L}^{-1}\right)\end{array}$ & $\begin{array}{c}\text { Method detection } \\
\text { limit (MDL) } \\
\mu \mathrm{g} \mathrm{L} \mathrm{L}^{-1}\end{array}$ \\
\hline 1 & Cypermethrin & $<0.40$ & 0.40 \\
2 & Phenthoate & $<0.40$ & 0.40 \\
3 & Chlorfenapyr & $<0.40$ & 0.40 \\
4 & Tralomethrin & $<0.40$ & 0.40 \\
5 & Tolfenpyrad & $<0.40$ & 0.40 \\
6 & Tefluthrin & $<0.40$ & 0.40 \\
7 & Imidacloprid & $<0.0025$ & 0.0025 \\
8 & Methomyl & $<0.050$ & 0.050 \\
9 & Acetamiprid & $<0.0025$ & 0.0025 \\
\hline
\end{tabular}

と, 豪雨により大量の雨水が河川水に含まれていたと考え られた ${ }^{17)}$ 。また, 水生生物への影響が懸念される $\mathrm{NH}_{4}-\mathrm{N} に$ ついては, $0.031 \mathrm{mg} \mathrm{L}^{-1}$ と低い值であり, 水生生物へ与え る影響は小さいと考えられた。

\section{$3 \cdot 2$ スクリーニング法による流出農薬測定結果}

本スクリーニング法は, JIS K0123: 2018 ガスクロマトグ ラフィー質量分析通則 11.5 検量線データベース法（以下, 検量線データベース法）において登録された検量線から半 定量分析を行うものである。 そのため, GC/MSのスク リーニング法の検出下限は, 登録された検量線最低濃度と 試料量 $(50 \mathrm{~mL})$ から算出した ${ }^{18)}$ 。また, LC/MS/MS につ
いてもスクリーニング法であることから，検出下限值の算 出方法は GC/MS に合わせ, 検量線の最低濃度を基に, 試 料量 $(40 \mathrm{~mL})$ から算出した ${ }^{18)}$.

GC/MS 及び LC/MS/MS のスクリーニング法の測定結 果と検出下限值を Table 6 に示す。また，河川水試料を用 いた添加回収試験結果を Table 7 に示す.なお, AIQS によ る測定（操作ブランク試料と河川水試料）では, 試料の準 備から前処理までの時間が約 15 分, GC/MS 測定時間が約 90 分, データ解析が約 30 分と合計 135 分間で終了した. LC/MS/MS を用いた測定 (検量線 8 濃度区と操作ブランク 試料と河川水試料) では, 試料の準備から前処理時間が約 15 分, 検量線試料の準備が約 30 分, LC/MS/MS 測定時間 が約 170 分, データ解析が約 30 分と合計 245 分で終了し た.

スクリーニング法による測定の結果, 流出農薬は検出下 限以下であった。 また，河川水試料を用いた添加回収試験 の結果, Methomylの回収率のみ $44 \%$ となり, 他の物質と 比べ低かった。 これは水溶解度が $58000 \mathrm{mg} \mathrm{L}^{-1}$ と高く, 抽 出溶媒のアセトニトリルへの分配が困難であったためと考 えられた，ただし，目標值（50-150％）に近い值が得られ たことから，スクリーニング法としては適用可能であると 判断した.

スクリーニング法による調査では, 流出農薬は検出され なかったが, 水稲農薬である Furametpyr が検出されてい た $\left(0.015 \mu \mathrm{g} \mathrm{L}^{-1}\right) .7$ 月は水稲栽培の時期であることから,

Table 7 Results of recovery tests using river water in a heavy rain disaster by screening method $(n=3)$

\begin{tabular}{|c|c|c|c|c|c|c|}
\hline No & $\begin{array}{c}\text { Target } \\
\text { compounds }\end{array}$ & $\begin{array}{l}\text { Recovery } \\
\text { Compounds }\end{array}$ & $\log P_{\text {ow }}{ }^{a b)}$ & $\begin{array}{l}\text { Water solubility/ } \\
\mathrm{mg} \mathrm{L}^{-1 \mathrm{a}) \mathrm{b})}\end{array}$ & $\begin{array}{c}\text { Recovery } \\
(\%)\end{array}$ & $\begin{array}{l}\text { C.V } \\
\text { (\%) }\end{array}$ \\
\hline 1 & Cypermethrin & & & & & \\
\hline 4 & Tralomethrin & Etofenprox & 7.05 & 0.001 & 80 & 2.1 \\
\hline 6 & Tefluthrin & & & & & \\
\hline 2 & Phenthoate & Phenthoate & 3.69 & 11 & 106 & 4.0 \\
\hline \multirow{3}{*}{3} & \multirow{3}{*}{ Chlorfenapyr } & Chlorpyrifos & 4.96 & 1.12 & 110 & 2.1 \\
\hline & & Benfluralin & 5.29 & 0.1 & 96 & 2.7 \\
\hline & & Dithiopyr & 4.75 & 1.4 & 105 & 3.1 \\
\hline 5 & Tolfenpyrad & Trifluralin & 5.34 & 0.184 & 85 & 4.1 \\
\hline 7 & Imidacloprid & Imidacloprid & 0.57 & 610 & 105 & 4.5 \\
\hline 8 & Methomyl & Methomyl & 0.6 & 58000 & 44 & 15 \\
\hline 9 & Acetamiprid & Acetamiprid & 0.80 & 4250 & 92 & 4.1 \\
\hline
\end{tabular}

a) Reference 10, b) Reference 22 . 

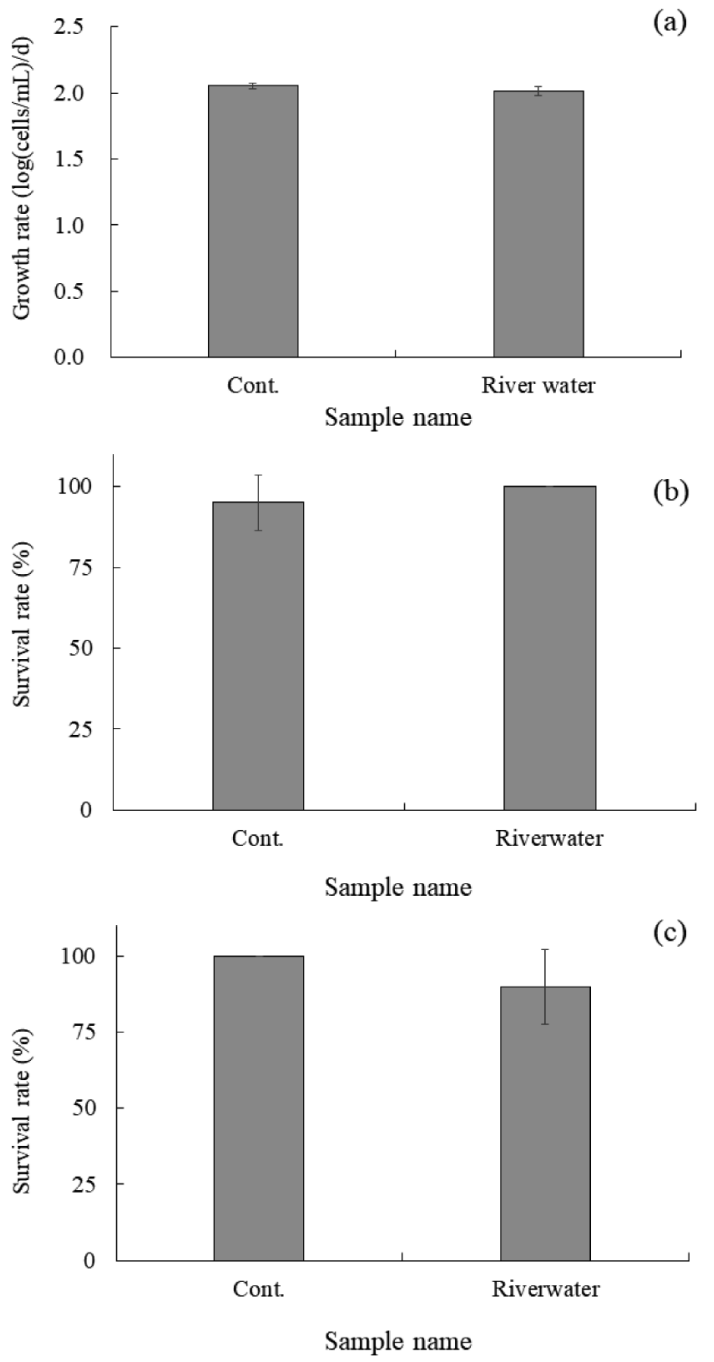

Fig. 4 Results of a bioassay for river water in a heavy rain disaster

(a) Algal growth inhibition test. (b) Daphnia magna, acute immobilization test. (c) Fish embryo acute toxicity test.

降雨により水田から当該農薬が流出してきたものと考えら れた. Furametpyrのような水稲農薬は平常時においても $0.048 \sim 1.3 \mu \mathrm{g} \mathrm{L}^{-1}$ の範囲で検出されており, 本調査で検出 された濃度は, 平常時と比べて 3 分の 1 ～ 86 分の 1 程度で あった ${ }^{19)}$.また, 農薬以外に Tridecane, Tetracosane, Dodecane, Anthracene が, それぞれ $0.48 \mu \mathrm{g} \mathrm{L} \mathrm{L}^{-1}, 0.72 \mu \mathrm{g}$ $\mathrm{L}^{-1}, 0.40 \mu \mathrm{g} \mathrm{L}^{-1}, 0.40 \mu \mathrm{g} \mathrm{L}^{-1}$ 検出された. 緊急時環境調査 では, 災害により漏洩・流出した化学物質かどうかの判定 が重要になるため, 平常時においてどのような化学物質が 検出されるかについて把握しておくことが望ましい. ま た, 蒸留水を用いた操作ブランク試験において流出農薬は 検出されなかった。

\section{3·3 Iminoctadine, Diquat, Paraquat の測定結果}

Iminoctadine, Diquat, Paraquatは土堙吸着性が高く,
試料中の有機物や無機物の影響を受けやすいことが報告さ れている ${ }^{10) 20(21)}$. 河川水試料を用いた添加回収試験では, Iminoctadine, Diquat, Paraquatの回収率がそれぞれ $0.43 \%, 0.75 \%, 0.29 \%$ で, C.Vがそれぞれ $58 \%, 12 \%$, $8.5 \%$ となり, ほとんど回収できていなかった。 これは $\mathrm{SS}$ が $220 \mathrm{mg} \mathrm{L}^{-1}$ と高いため, 河川水試料中の粒子などの影響 を受けたためと考えられた.よって, 河川水試料へ本法を 適用できなかった。 また， ろ過ディスクへの吸着を確認す るため, 蒸留水を用いた添加回収試験を実施した結果, Iminoctadine, Diquat, Paraquatの回収率はそれぞれ, $81 \%, 90 \%, 98 \%$ となり, C.V 值は $12 \%, 1.0 \%, 3.8 \%$ であった. Iminoctadine の回収率が $81 \%$ となり，ろ過 ディスクへの吸着による損失も確認されたものの, 回収率 は $80 \%$ 以上でありおおむね良好であった。 また, 蒸留水 を用いた操作ブランク試験において Iminoctadine, Diquat, Paraquatは検出されなかった.

\section{$3 \cdot 4$ 生物応答試験結果}

生物応答試験の結果を Fig. 4 に示す.

藻類生長阻害試験の対照区と試験濃度区（試料濃度 $80 \%$ ）の生長速度はそれぞれ 2.05，2.01 となり，生長阻害 率は $1.95 \%$ であった。 また, $\mathrm{t}$ 検定（有意水準 $5 \%$ ）によ り対照区と試験濃度区の生長速度の結果を解析した結果, 対照区と比較して有意差は認められなかった（p=0.073）.

ミジンコ急性遊泳阻害試験の対照区と試験濃度区（試料 濃度 $100 \%$ ）の生存率は, それぞれ $95 \%$ ，100\% となっ た. 試験濃度区において死亡する個体はなかったため, Wilcoxon 検定は実施しなかった.

魚類胚期急性毒性試験の対照区と試験濃度区（試料濃度 $100 \%$ ）の生存率は，それぞれ $100 \%$ ，90％となった. 陽 性対照区の生存率は $0 \%$ であった. Internal plate control の生存率は $100 \%$ であった。 また, Wilcoxon 検定（有意 水準 $5 \%$ ）により対照区と試験濃度区の生存率の結果を解 析した結果, 対照区と比較して有意差は認められなかった $(\mathrm{p}=0.13)$.

生物応答試験の結果より, 今回の豪雨において河川水試 料中の化学物質が水生生物へ悪影響を与える可能性は低い ことが示された。

$$
4 \text { 結 言 }
$$

豪雨災害で発生した農薬流出事故を受けて実施した有害 化学物質のスクリーニング法では，採水から結果の報告ま で 1 日で完了し, 緊急時環境調査として非常に有効であっ た。しかし，スクリーニング法の適用範囲外である Iminoctadine, Diquat, Paraquatのような親水性が強く, 河川水試料中の有機物質や無機物質の影響を受けやすい物 質については, 緊急時環境調査用に分析法を開発し準備し 
ておく必要がある.

次に水生生物 3 種を用いた生物応答試験では, 生物影響 がないことを確認できた。 さらに，生物応答試験は，機器 分析で把握が困難であった Iminoctadine, Diquat, Paraquat等のリスク評価を補完する方法としても有効であ ると考えられる.

なお, 流出した農薬類は, 後日容器ビンごとすべて回収 されたため, 周辺環境を污染していないことが判明した.

\section{謝辞}

本研究の一部は，日本学術振興会科学研究費補助金「基 盤研究 (C)」（19K12352）と公益財団法人河川財団の河川 基金助成事業（2020-5211-012）によって実施したことを付 記し，ここに謝意を表します。

\section{文献}

1) 中央防災会議：平成 30 年 6 月 防災基本計画 第 13 編危険物等災害対策編第 2 章災害応急対策第 2 節災害の拡大防止活動, <http://www.bousai.go.jp/ taisaku/keikaku/pdf/kihon_basic_plan180629.pdf>, (accessed 2020-11-26).

2) 内閣官房 : 平成 30 年 12 月 14 日 国土強䩲化基本 計画 第 3 章国土強勒化の推進方針 2 施策分野ごと の国土強勒化の推進方針 (11) 環境, <https://www. cas.go.jp/jp/seisaku/kokudo_kyoujinka/pdf/ kk-honbun-h301214.pdf>, (accessed 2020-11-26).

3) K. Kadokami, K. Tanada, K. Taneda, K. Nakagawa : J. Chromatogra. A, 1089, 219 (2005).

4) 古閑豊和, 宮脇 崇：分析化学 (Bunseki Kagaku), 68, 417 (2019).

5) 古閑豊和, 宮脇 崇：分析化学 (Bunseki Kagaku), 69, $121(2020)$.

6) T. Miyawaki, K. Tobiishi, S. Takenaka, K. Kadokami : Soil and Sediment Contamination, 27, 31 (2018).

7) 古閑豊和, 柏原 学, 平川周作, 宮脇 崇, 志水信 弘, 石橋融子：用水と廃水 (Yosui to Haisui), 62 , 349 (2020).

8) 内閣府：令和 2 年 7 月豪雨による被害状況等に ついて, <http://www.bousai.go.jp/updates/ r2_07ooame/pdf/r20703_ooame_38.pdf>, (accessed
2020-11-26)

9) 気象庁：過去の気象デー夕検索, <http://www. data.jma.go.jp/obd/stats/etrn/view/daily_a1. php?prec_no $=82 \& b l o c k \_n o=0790 \&$ year $=2020 \& \mathrm{mont}$ $\mathrm{h}=7 \&$ day $=\&$ view $=>$, (accessed 2020-11-26).

10）一般社団法人日本植物防疫協会：農薬ハンドブッ ク 2016 年版 (2016).

11) 小林憲弘, 久保田領志, 佐々木俊哉, 五十嵐良明 : 環境科学会誌 (Kankyou Kagakukaishi), 28, 117 (2015).

12）一般財団法人日本規格協会 : JISハンドブックJIS K 0102: 2016 工場排水試験方法 (2019).

13) 古閑豊和, 柏原 学, 平川周作, 志水信弘, 石橋融 子：環境化学 (Kankyou Kagaku), 29, 67 (2019).

14) OECD : OECD Guidelines for the testing of chemicals 236, Fish embryo acute toxicity (FET) test (2013).

15) R Core Team: R: Language and Environment for Statistical Computing. R Foundation for Statistical Computing. Vienna, Austria. Available at <http:// www.R-project.org/>, (accessed 2020-7-16).

16) 福岡県：公共用水域測定結果, <https://www.pref. fukuoka.lg.jp/contents/koukyouyousuiiki.html>, (accessed 2020-12-08).

17) 環境省：令和元年度酸性雨調査結果, 湿性沈着モ ニタリング結果，令和元年度電気伝導率 月·年平 均值 <http://www.env.go.jp/air/acidrain/ monitoring/r01/mat03-r1.pdf $>$, (accessed 2020-1208).

18）一般財団法人日本規格協会：JISハンドブック JIS K 0123:2018，ガスクロマトグラフィー質量分析通則 (2019).

19）古閑豊和，松本源生，石橋融子，土田大輔，馬場義 輝：第 49 回日本水環境学会年会講演集, 531 (2015).

20) 木下輝昭, 小杉有希, 鈴木俊也, 保坂三継, 中江 大：水環境学会誌 (Mizu Kankyo Gakkaishi), 38, 49 (2015).

21) 厚生労働省食品安全委員会：農薬評価書イミノク タジン, <https://www.mhlw.go.jp/content/11120000/ 000556144.pdf>, (accessed 2021-03-23).

22) United States National Library of Medicine : ChemIDplus of TOXNET, avilable from, <https:// chem.nlm.nih.gov/chemidplus/>, (accessed 202011-25). 


\title{
Survey of Organic Pollutants in River Water by a Target Screening Method and a Bioassay in Heavy Rainfall Disasters
}

\author{
Toyokazu KogA $^{* 1}$, Yuko IsHIBASHI ${ }^{1}$ and Takashi MrYAWAKI ${ }^{2}$ \\ * E-mail : t-koga@fihes.pref.fukuoka.jp
}

\begin{abstract}
${ }^{1}$ Fukuoka Institute of Health and Environmental Sciences, 39, Mukaizano, Dazaifu-shi, Fukuoka 818-0135
${ }^{2}$ Faculty of environmental engineering, The University of Kitakyushu, 1-1, Hibikino, Wakamatsu-ku, Kitakyushu-shi, Fukuoka 808-0135
\end{abstract}

(Received April 14, 2021; Accepted June 2, 2021)

In July 2020, heavy rains caused floods in the Kyushu region, resulting in an accidental spillage of 12 pesticides from a pesticide storehouse upstream of the Chikugo River tributary. In this study, we analyzed the spilled pesticides by a target screening method using GC/MS and LC/MS/MS. Some of the spilled pesticides (iminoctadine,diquat,paraquat) were measured by direct injection using LC/MS/MS. The toxicity of the pesticides to aquatic organisms was assessed by bioassays using algae (Raphidocelis subcapitata), water fleas (Daphnia magna), and fish (Danio rerio) embryos. As a result, no spilled pesticides were detected and no toxic effects were observed on aquatic organisms. The screening method using GC/MS and LC/ MS/MS determined chemicals in 1 day, i.e., from sampling to reporting the survey results. The recovery tests of pesticides, using river water in a heavy rain disaster by a target screening method, were at generally acceptable levels (recovery rate: 44-110\%) compared with the target recovery rates (50-150\%). However, the recovery rate of highly hydrophilic pesticides (iminoctadine,diquat,paraquat) was $0.29-0.75 \%$. Therefore, it is necessary to develop a screening method for hydrophilic substances used in heavy rain disasters.

Keywords: target screening; LC/MS/MS; GC/MS; bioassay; AIQS. 